Ethiopian Journal of Environmental Studies \& Management 10(3): 389 - 403, 2017.

ISSN:1998-0507

doi: https://dx.doi.org/10.4314/ejesm.v10i3.9

Submitted: January 13, 2017

Accepted: May 02, 2017

\title{
SPATIO-TEMPORAL ANALYSIS OF LAND SURFACE TEMPERATURE VARIATIONS IN THE RAPIDLY DEVELOPING AKURE AND ITS ENVIRONS, SOUTHWESTERN NIGERIA USING LANDSAT DATA
}

*IBITOYE, M.O., ADERIBIGBE, 0.G., ADEGBOYEGA, S.A. AND ADEBOLA, A.0.

Department of Remote Sensing and Geoscience Information System, Federal University of Technology Akure, Nigeria

\begin{abstract}
The study attempted to assess land surface temperature (LST) variations in Akure, a millennium development city, and its environs, in Nigeria. The importance of LST as a vital component in global climate change cannot be over emphasized because as the greenhouse gases in the atmosphere increases, the LST also increases. Spatio-temporal assessment of LST variation is therefore becoming imperative to identify the contributing factors and the corresponding magnitude of contributions to the variation using remote sensing and GIS techniques. Landsat TM image of 1991, Landsat ETM+ image of 2002 and Landsat OLI/TIRS of 2015 were used and processed using ArcGIS 10.1, IDRISI and Erdas imagine 9.3 to generate indices such as Normalized Difference Vegetation Index NDVI, Land Use Land Cover (LULC) and Land Surface Temperature (LST). The finding showed that the changes, both spatial and temporal within the land uses influenced the temperature variations in the study area. The built-up, rock outcrops, farmland and vegetation land uses recorded mean temperature change of $4.91 \pm 0.7,3.53 \pm 0.3,3.14 \pm 0.2$ and $1.87 \pm 0.3$ respectively, with their respective yearly temperature increase estimated at $0.21^{\circ} \mathrm{C}$, $0.15^{\circ} \mathrm{C}, 0.14^{\circ} \mathrm{C}$ and $0.08^{\circ} \mathrm{C}$ between 1991 and 2015 . The study concludes that the observed increasing variations in LST in all the land uses has been precipitated by rapid land use conversion and modification that may have strong tendency to usher in climate related problems such as flood, human discomfort and other associated environmental hazards. An effective land use policy is therefore suggested to complement Federal Government 'green policy' urban environment.
\end{abstract}

Key Words: LST variation, Land Use Land Cover, NDVI, GIS, Remote sensing technique, Nigeria

\section{Introduction}

Land surface temperature (LST) is one of the important parameters in urban climate as it serves as an indicator for measuring urban heat islands (UHIs) (Voogt and Oke, 2003; Feizizadeh and
Blaschke, 2013). Surface temperature of an urban area is influenced by many factors like the length of day, season, wind, ocean currents, clouds, topography, location, rural surroundings, alteration in land use types change, building material

*Corresponding Author: Ibitoye, M.O.

Email: geomattim@gmail.com 
and city geometry (Valsson and Bharat, 2009; Lo and Quattrochi, 2003) and it has indirect but considerably significant influence on air temperatures, especially the canopy layer that is closest to the surface (Zhang and Wang, 2008). The green areas covered by vegetation act as lungs of the city and help to regulate the temperature thus bringing about low temperature in the immediate surroundings (Yue et al., 2009). The replacement of the vegetation and other natural surfaces by human activities like asphalt, concrete, metal, in urban areas has environmental implications including reduction in evapo-transpiration, rapid run-off and increase in surface temperatures leading to creation of UHIs (Singh et al., 2014). LST is believed to correspond closely with the Land Use/Land Cover (LULC) resulting to inter-seasonal variations in surface temperature of different land uses/cover. For instance, urbanization has been the main driver of land use land cover change in human history that has a great impact on climate (Zemba et al., 2010; Musa et al., 2012). With the covering of surface with buildings, roads and other impervious surfaces ( $\mathrm{Xu}$ and Cheng, 2004), urban areas generally have higher solar radiation absorption, and a greater thermal capacity and conductivity such that heat is stored during the day and released by the night (Akinbode et al., 2008). Therefore, urban areas tend to experience a relatively higher temperature compared with the surrounding rural areas. This thermal difference in conjunction with heat released from urban houses, transportation and industry contribute to the development of Urban Heat Island
(UHI) (Rajendran et al., 2009, Effat and Hassan, 2014).

The rapid growth in human population and economic output per capital has been an unprecedented features (Cohen, 2004 and Sackey, 2008), impacting great consequences on the global environment over the past century (Rosa et al, 2004). The temperature difference between the urban and the rural areas are rising to several degrees with special urban, topographical and meteorological conditions (Mather, 1986). The fact that urban areas tend to be warmer has been well studied and documented elsewhere in the world (Arnfield, 2003; Samuels, 2004; Svensson and Tarvainen, 2004). Apart from the fact that most of the studies are sparse in the developing countries like Nigeria and in particular Akure and its environs, comprehensive study on the drivers of spatio-temporal variation in the urban land surface temperature is yet to be given adequate attention.

Akure and its environs is one of the fast growing urbanized sectors of Ondo State, Nigeria with high influx population that responsible for increase demand for housing and business centres. These activities put pressure on land resources in and around urban centers and the continual change in the land uses that affects both the micro and macro climate of the area. Based on this premise, the main objective of the study is to assess the spatio-temporal variation of LST among the various land use in the study area with a view to providing LST baseline information for the study area.

Several methods have been adopted in the past to estimate surface temperature based on data collected from meteorological stations (Akinbode et al., 
2008). However, with the advance in space technology, remote sensing method is mostly adopted particularly when surface temperature of wider areas are to be determined (Alavipanah et al., 2007; Akhoondzadeh and Saradjian, 2008; Ifatimehin et al., 2011; Rajeshwari and Mani, 2014). Since the 1970s, satellitederived images such as Landsat Thematic Mapper (LTM), surface temperature data have been utilized for regional climate analyses on different scales (Rajeshwari and Mani, 2014). It is on this premise that remote sensing technology and GIS are adopted for the extraction of land surface temperature in the study area.

\section{Study Area}

The study area is Akure and its environ in Ondo State, Nigeria. It comprises both the Akure South and North Local government Areas (LGAs) covering an approximate area of 991 square kilometres within the central part of the state. It is located within latitudes $7^{\circ} 7^{\prime} \mathrm{N}$ and $7^{\circ} 44^{\prime} \mathrm{N}$, and longitudes $5^{\circ}$ $07^{\prime} \mathrm{E}$ and $5^{\circ} 47^{\prime} \mathrm{E}$. It shares boundaries in the North with Ikere Local Government Area (LGA) in Ekiti State, and in the North West by Ifedore LG and in the East by Owo/ Ise LG and in the south by Idanre LGA (Figure 1). It lies on a relatively flat plain of about $250 \mathrm{~m}$ above sea level within the Southwestern Nigerian. The area towards Ado-Ekiti and Idanre are hilly and studded with large granite formation, rising to $410 \mathrm{~m}$ and 496m above sea level respectively. These granitic formations are said to be of volcanic origin, underlained by basement complex rocks, which are mostly impermeable gneisses and granites. (Aderoju et al., 2013)

It is predominantly Yoruba speaking stock with Akure as the major dialect. The major town is Akure which serves as the state capital and the administrative headquarters of Akure South LGA. Others are Iju/Itaogbolu, the headquarters of Akure North LGA, Oba Ile and Oda to mention but a few. The area is one of the fasted growing urban centres in Nigeria and has a population of 484798 (Federal Bureau of Statistic, 2007). The area experiences warm humid tropical climate, with average rainfall of about $1500 \mathrm{~mm}$ per annum with the little dry season in August and annual temperature range between $21.4^{\circ} \mathrm{C}$ and $31.1^{\circ} \mathrm{C}$, and relative humidity of about $77.1 \%$ (Nigerian Meteorological Agency, Oshodi Lagos, 1980 -2007 data).

The vegetation is tropical rainforest and drained by River Ala and its tributaries downwards to the Atlantic Ocean (Barbour et al., 1982; Iloeje, 1977; Uluocha and Ekop, 2002; Ayeni, 2011). The majority of the people in the area are predominantly farmers that engage in both arable farming such as yam, cocoyam, cassava, corn, plantain etc and cash crops such as cocoa, Kola nut, palm tree etc. 


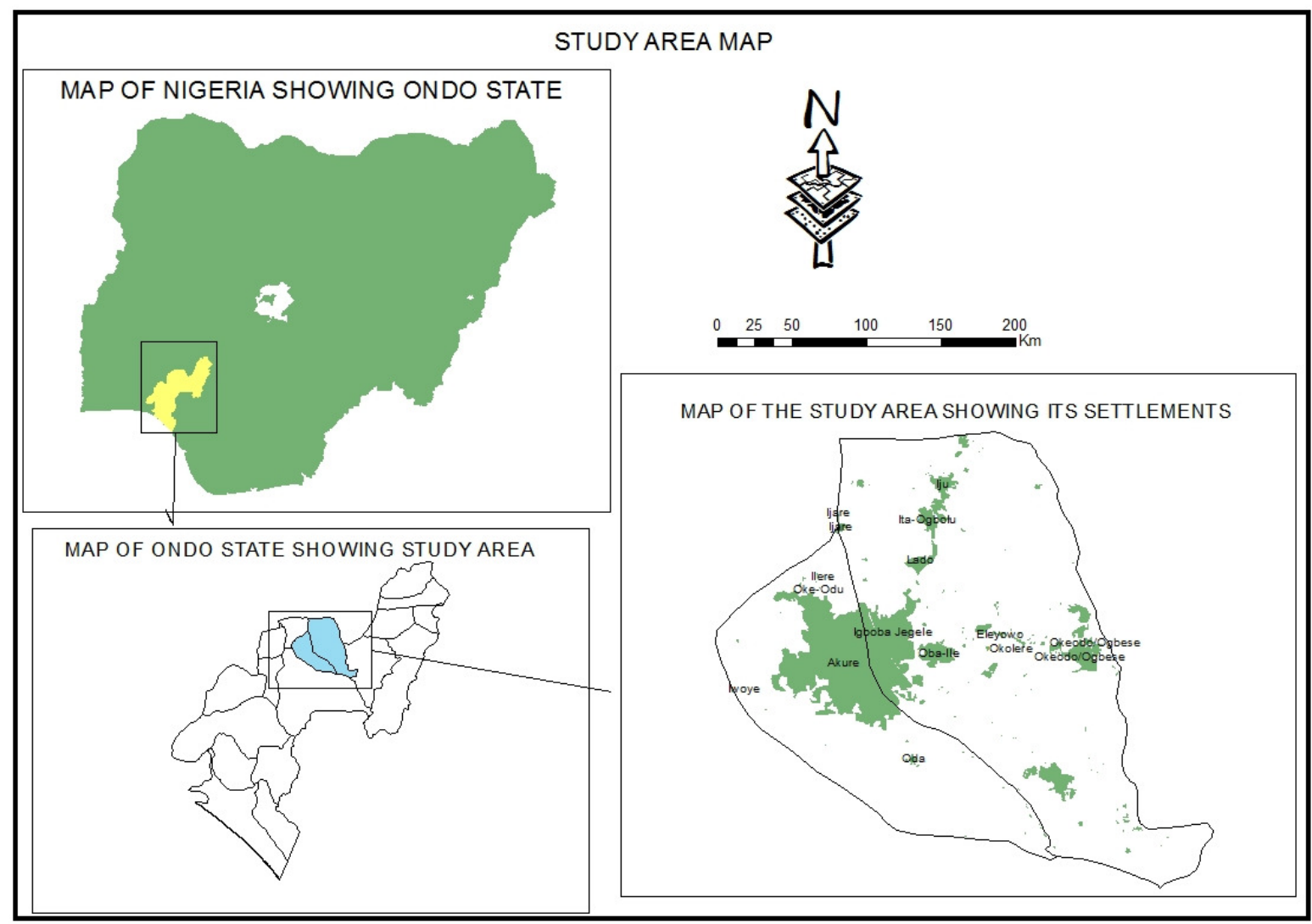

Figure 1, Map showing the study

\section{Materials and Methods}

\section{Data Types and Sources}

The study used a time series of Landsat satellite images which include Operational Land Imager (OLI) and Thermal Infrared Sensor (TIRS) of January 2015, Enhanced Thematic Mapper Plus (ETM+) of January 2002 and Thematic Mapper of January 1991. The satellite images were obtained from the U.S. Geological Survey (USGS). In addition, Google Earth image, topographical maps collected from Ondo
State Ministry of Lands and Housing and the shape file of the study area were also used to prepare the land cover maps. Details of the imagery used are given in Table 1. All the necessary criteria required in other to have a good and quality image free of geometric and radiometric errors for this study were considered before downloading the images. Therefore, there was no geometric or radiometric corrections performed on the images before used. 
Table 1: Details of acquired and used satellite imagery

\begin{tabular}{llllll}
\hline Satellite & Sensor & $\begin{array}{l}\text { Acquisition } \\
\text { Date }\end{array}$ & Path/ Row & $\begin{array}{l}\text { Cloud } \\
\text { Cover }\end{array}$ & Source \\
\hline Landsat 8 & OLI/TIRS & $15 / 01 / 2015$ & $190 / 055$ & $0.01 \%$ & USGS \\
Landsat 7 & ETM+ & $03 / 01 / 2002$ & $190 / 055$ & $0 \%$ & USGS \\
landsat 4 & TM & $05 / 01 / 1991$ & $190 / 055$ & $0 \%$ & USGS \\
\hline
\end{tabular}

Source: Compiled from Images obtained from US Geological Survey

Methods of Data Processing and Analysis

The land use land cover (LULC) classification of the study area was carried out using supervised image classification technique with ArcMap 10.1. Samples of each land use cover class in the digital images were selected for the classification. The training sample manager on ArcMap 10.1 allows the user to create a signature file by training the software to recognize the spectral signature of the individual classes on the image. Therefore, image classification algorithm uses the training sample to identify the land cover classes in the entire image. The classification of land cover is based on the spectral signature defined in the training set. Maximum Likelihood Algorithm which classifies images according to the covariance and variance of the spectral response patterns of a pixel.

The features on the image were grouped into four different classes based on their spectral signatures and the grouping was done for the January images of landsat 4 (TM), landsat 7 ETM+ and landsat 8 OLI/TIRS for year 1991, 2002 and 2015 respectively. These classes include built up, vegetation, bare surfaces/ farmlands and rock outcrops. The total area covered by each land use class in each year was generated using the field calculator of ArcGIS 10.1.
Normalized Differential Vegetation Index (NDVI) for the study area was calculated as ratio between measured reflectivity in the red and near infrared (NIR) portions of the electromagnetic spectrum. That is, NDVI= (NIR-RED) / (NIR+RED). These two spectral bands were chosen because they were most affected by the absorption of chlorophyll in leafy green vegetation and by the density of green vegetation on the surface. The contrast for vegetation was maximum in red and NIR bands (Bindi, et al. 2009). NDVI was used to identify devegetated regions. Low values of this index represented devegetated areas. Comparisons were made with composite images to derive the threshold, and then devegetated areas were identified. Healthy vegetation contains large quantities of chlorophyll, the substance that gives most vegetation its distinctive green colour. The reduction in chlorophyll content results in a decrease in reflectance in the green region and internal leaf damage results in a decrease in near-infrared reflectance. NDVI was therefore used for monitoring vegetation changes in the study area between 1991 and 2015.

LST values were calculated using radian reflectance values of the three Landsat images which were transformed to radiant surface temperature values in Kelvin using the following equation: $\mathrm{Tb}=\mathrm{k} 2 /(\mathrm{In}(\mathrm{k} 1 / \mathrm{L} \lambda+1))$ 
$\mathrm{Tb}=$ Surface Temperature in Kelvin

$\mathrm{K} 1$ = Calibration Constant 1 (607.76 for TM and 666.09 for ETM+)

K2 = Calibration Constant 2 (1260.56 for TM and 1282.71 for ETM+)

The Surface temperature in Kelvin was finally converted to surface temperature in degree Celsius (Tc) using the following equation; $\mathrm{Tc}=\mathrm{Tb}-273$.

The thermal bands of landsat 4,7 and 8 were used to generate the land surface temperature image (LST) of the area. The thermal bands for landsat 8 OLI/TIRS are bands 10 and 11, for land sat 7 ETM+, the bands are band 6_VCID_1 and band 6_VCID_2. The thermal band for landsat 4 TM id is band 6. The thermal band parameters of the landsat series used to generate the LST for the study is shown in Table 2.

Table 2: Thermal bands of landsat 4,7 and 8 used for this analysis

\begin{tabular}{llllll}
\hline & $\begin{array}{l}\text { LANDSAT } 8 \\
\text { OLI/TIRS }\end{array}$ & & $\begin{array}{l}\text { LANDSAT 7 } \\
\text { ETM+ }\end{array}$ & $\begin{array}{l}\text { LANDSAT 4 } \\
\text { TM }\end{array}$ \\
& BAND 10 & BAND 11 & $\begin{array}{l}\text { BAND } \\
\text { 6_VCID_1 }\end{array}$ & $\begin{array}{l}\text { BAND_VCID_2 } \\
\text { 6_VAND 6 }\end{array}$ \\
RADIANCE & & & & & \\
MULTIPLIER & 0.000334 & 0.000334 & 0.067 & 0.037 & 0.055 \\
RADIANCE & & & & & \\
ADD & 0.1 & 0.1 & -0.067 & 3.163 & 1.182 \\
K1 & 774.89 & 480.89 & 671.62 & 671.62 & 671.62 \\
K2 & 1321.08 & 1201.14 & 1284.3 & 1284.3 & 1284.3 \\
\hline
\end{tabular}

\section{Result}

\section{Urban growth in the study area}

The four LULC types were identified and presented in Table 1. The table showed a significant urban growth by increasing from $7.25 \mathrm{~km}^{2}$ in 1991 to $75.40 \mathrm{~km}^{2}$ in 2015 with an increase of 2.8 $\mathrm{km}^{2} / \mathrm{yr}$. Figures $2 \mathrm{a}, \mathrm{b}$ and $\mathrm{c}$ showed the spatial occurrence and areal extent of the urban growth in 1991, 2002 and 2015, respectively. There was very little growth $(0.80 \%)$ observed within the urban land use between 1991 and 2002 but the growth was remarkably increased by $5.97 \%$ between 2002 and 2015. The result of NDVI as shown in Figures $3 a, b$ and $\mathrm{c}$ further confirmed the dynamism of urban development as the NDVI values increased towards the urban periphery. 
Table 3: LULC in the study area

\begin{tabular}{|c|c|c|c|c|c|c|c|c|}
\hline CLASS & $\begin{array}{l}\text { AREA (Sq. } \\
\text { Km) } \\
\text { JAN 91 }\end{array}$ & $\begin{array}{l}\text { AREA (\%) } \\
\text { JAN } 1991\end{array}$ & $\begin{array}{l}\text { AREA (Sq. } \\
\text { Km) } \\
\text { JAN } 2002\end{array}$ & $\begin{array}{l}\text { AREA (\%) } \\
\text { JAN } 2002\end{array}$ & $\begin{array}{l}\text { AREA } \\
\text { (Sq. Km) } \\
\text { JAN 2015 }\end{array}$ & $\begin{array}{l}\text { AREA } \\
(\%) \\
\text { JAN } 2015\end{array}$ & $\begin{array}{l}\text { Changes in } \\
\text { land use (1991- } \\
2015) \text { in sq.km }\end{array}$ & $\begin{array}{l}\mathrm{Km}^{2} \\
\text { per } \\
\text { year }\end{array}$ \\
\hline BUILT UP & 7.25 & 0.72 & 13.25 & 1.31 & 75.40 & 7.48 & 68.15 & +2.8 \\
\hline VEGETATION & 119.84 & 84.46 & 548.52 & 54.47 & 487.59 & 48.02 & 367.75 & +15.3 \\
\hline FARMLAND & 850.41 & 11.9 & 421.27 & 41.84 & 382.82 & 38.02 & 467.59 & -19.5 \\
\hline ROCK & 29.35 & 2.91 & 23.79 & 2.36 & 61.02 & 6.06 & 31.67 & -1.3 \\
\hline TOTAL & 1006.86 & 100 & 1006.86 & 100 & 1006.86 & 100 & & \\
\hline
\end{tabular}

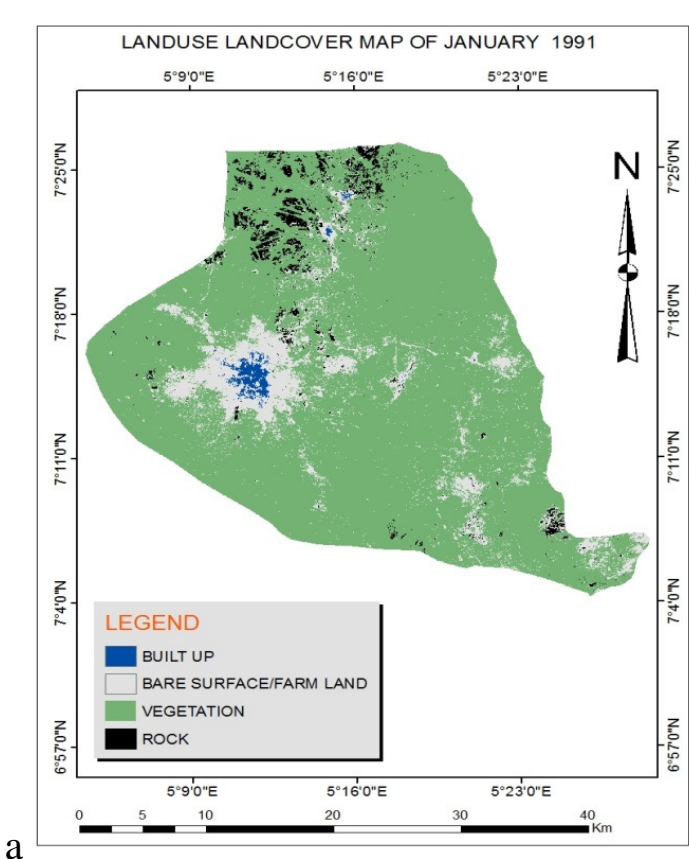

LAND USE LAND COVER MAP OF AKURE. JAN 2002
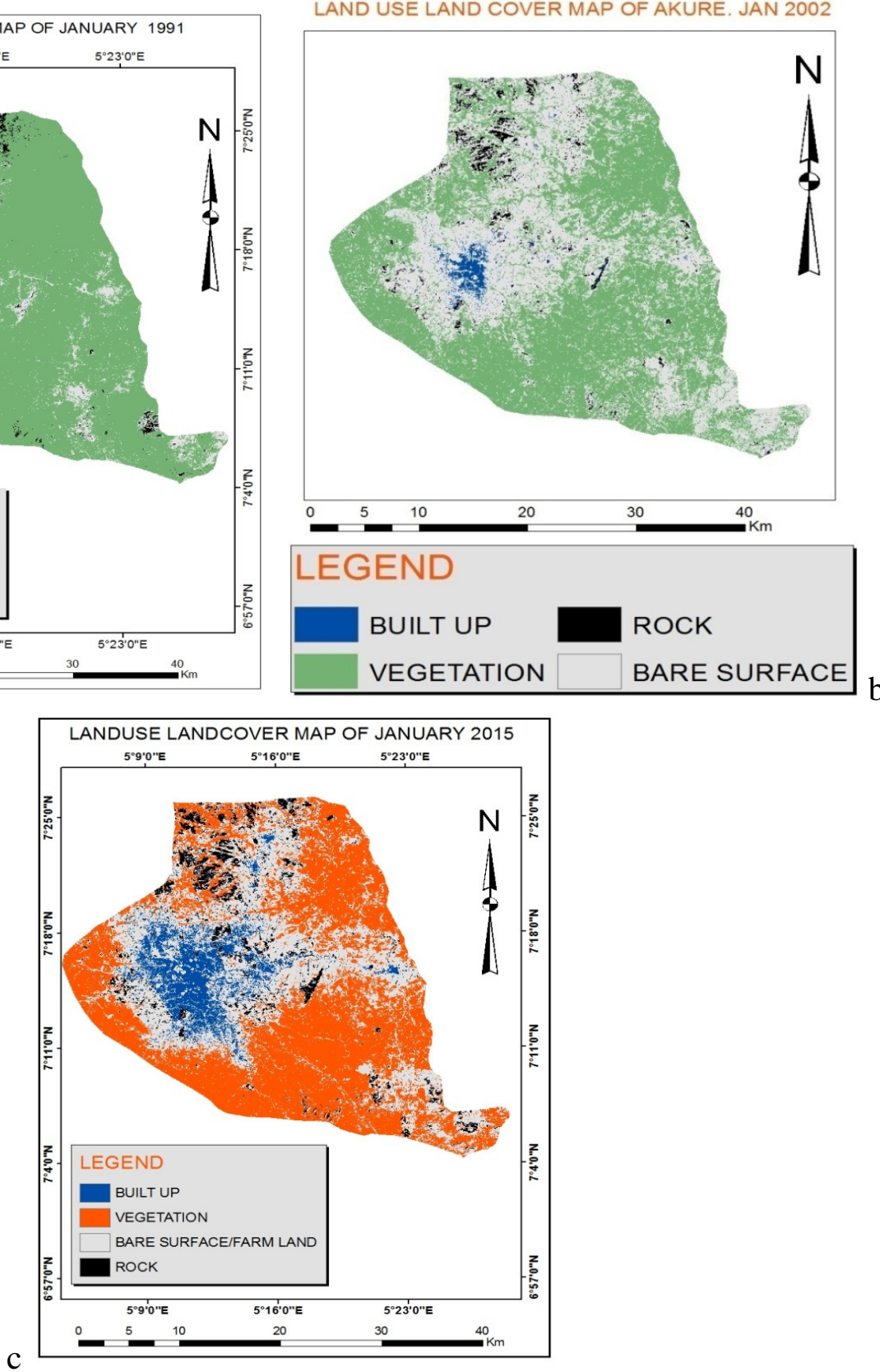

Figure 2a-c: Map showing land use land cover of the study area in (a) 1991 (b) 2002 and (c) 2015 

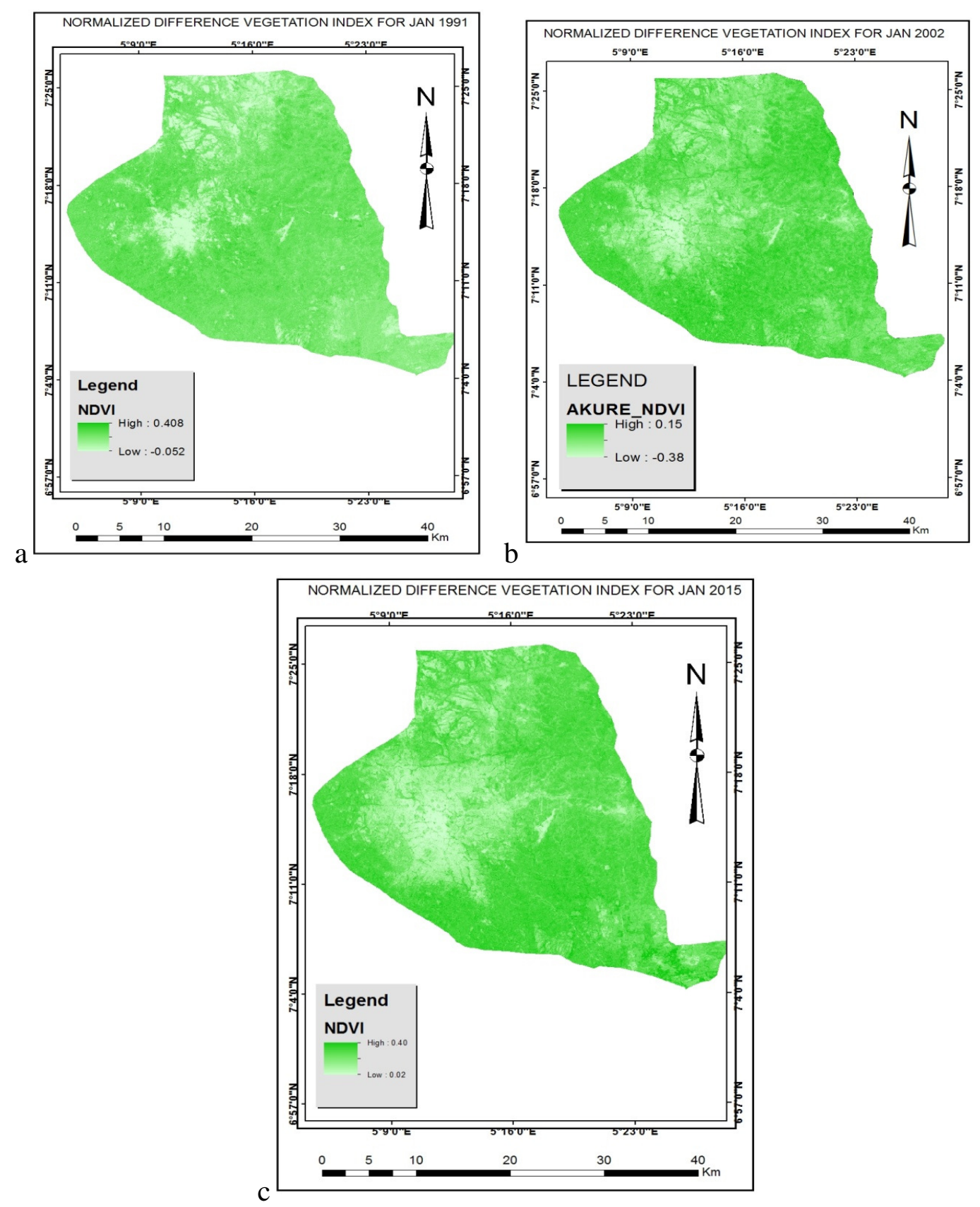

Figures 3a-c: Map showing the NDVI values of the study area in (a) 1991 (b) 2002 and (c) 2015

\section{Characteristics of radiant of Land Surface Temperature}

Table 5 showed the average radiant of LST in the study area on land use land cover based. The result further showed that the urban growth had contributed to the increase in surface temperature of the metropolis by $4.9^{0} \mathrm{C}$; that is, from $29.3^{0} \mathrm{C}$ to $34.2^{0} \mathrm{C}$. followed in values were rock outcrops and farmland with $3.53^{\circ} \mathrm{C}$ and $3.14^{0} \mathrm{C}$, respectively. 
Table 4: Temperature changes among the land uses in Degree Celsius

\begin{tabular}{|c|c|c|c|c|c|}
\hline YEAR & 1991 & 2002 & 2015 & $\begin{array}{l}\text { MEAN } \\
\text { TEMPERATURE } \\
\text { CHANGE (1991- } \\
\text { 2015) }\end{array}$ & $\begin{array}{l}\text { ANNUAL } \\
\text { TEMPERATURE } \\
\text {.INCREASE }\end{array}$ \\
\hline BUILT UP & $29.31 \pm 0.5$ & $30.14 \pm 0.9$ & $34.22 \pm 0.7$ & $4.91 \pm 0.7$ & 0.21 \\
\hline VEGETATION & $21.97 \pm 0.2$ & $16.26 \pm 0.3$ & $23.84 \pm 0.3$ & $1.87 \pm 0.3$ & 0.08 \\
\hline FARMLAND & $24.67 \pm 0.1$ & $18.49 \pm 0.2$ & $27.81 \pm 0.3$ & $3.14 \pm 0.2$ & 0.14 \\
\hline $\begin{array}{l}\text { ROCK } \\
\text { OUTCROPS }\end{array}$ & $26.11 \pm 0.1$ & $21.91 \pm 0.5$ & $29.64 \pm 0.3$ & $3.53 \pm 0.3$ & 0.15 \\
\hline
\end{tabular}
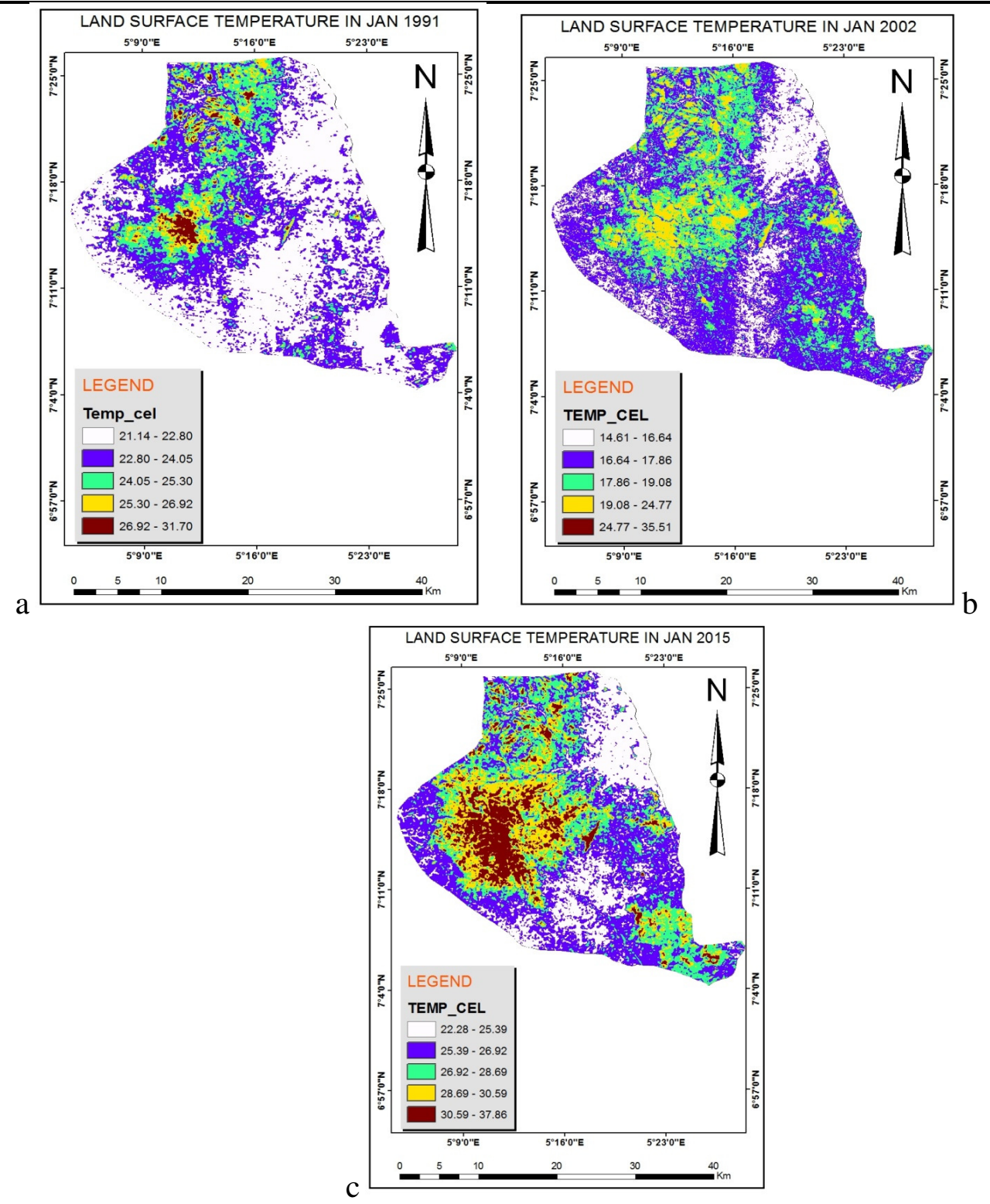

Figures 4a, b \& c: Map showing the LST of the study area in (a) 1991 (b) 2002 and (c) 2015 


\section{Relationship between LST, LULC and} NDVI

Figures $5 \mathrm{a}, \mathrm{b} \& \mathrm{c}$ showed a close relationship between LST, LULC and NDVI. From the figures, it was observed that over the study period very low NDVI values $(-0.052$ for $1991,-0.38$ for 2002 and 0.02 for 2015) were recorded in the urban while non-urban (vegetation or

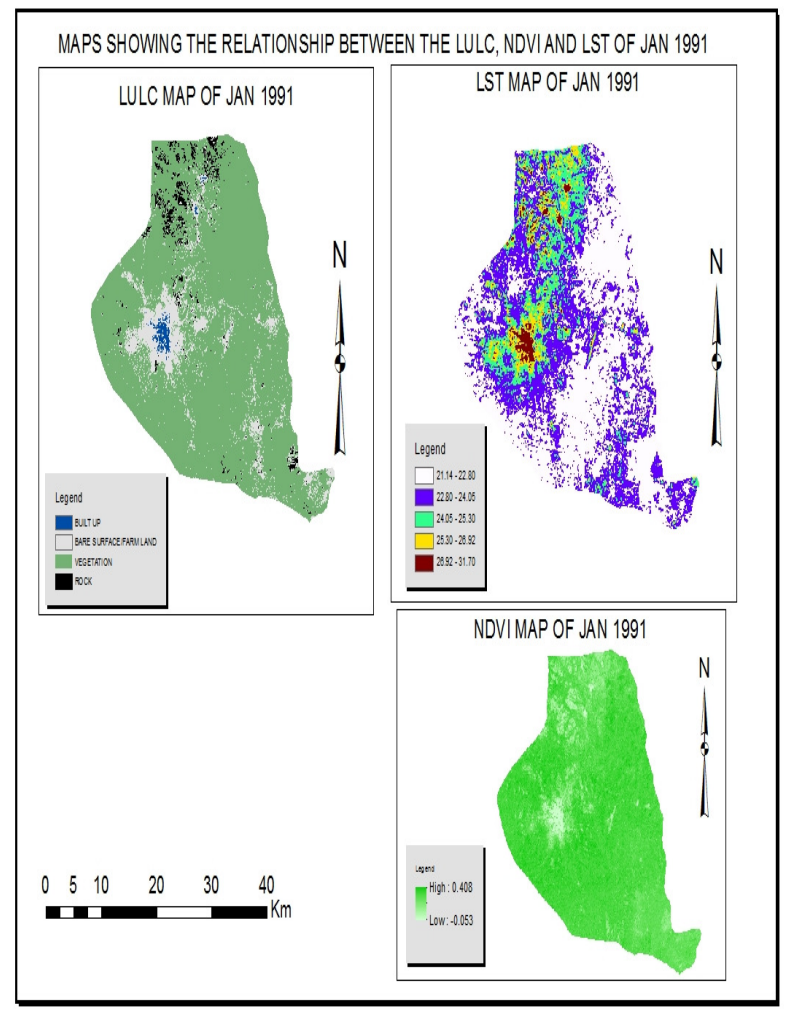

Figure 5 (a) showing the relationship between LULC, LST and NDVI of the study area in 1991 rural) areas recorded moderately high NDVI values of 0.41 for 1991, 0.15 for 0.15 and 0.40 for 2015). It was also observed that NDVI and LST were closely correlated in all LULC categories especially, urban and non urban (vegetation, Farmland and Rock outcrops). 


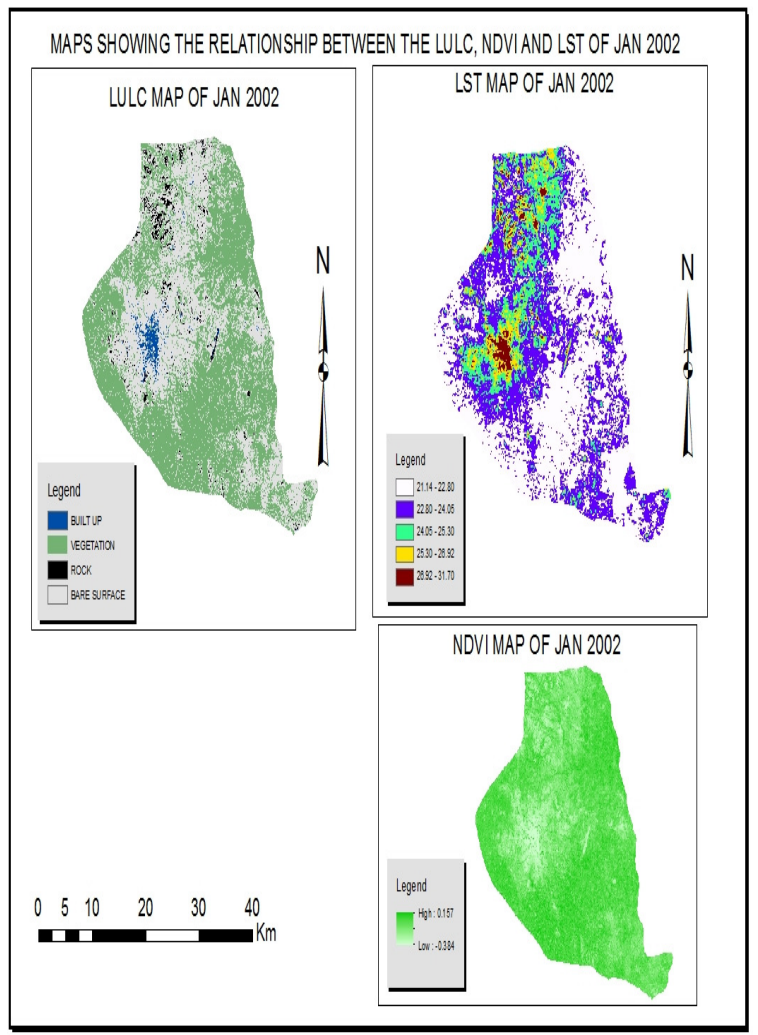

Figure 5 (b) showing the relationship between LULC, LST and NDVI of the study area in 2002

\section{Discussion}

Four categories of land use were indentified in the study area (Table 3). Built up maintained a constant increase within the time space of 24 years (19912015 ) with $68.15 \mathrm{~km}^{2}$ which translated to $2.8 . \mathrm{km}^{2}$ per annum while Farmland was in a constant decrease from $850.41 \mathrm{~km}^{2}$ in 1991 to $382.82 \mathrm{~km}^{2}$ in 2015 at the rate of $19.5 \mathrm{~km}^{2}$ per year. Vegetation and Rock outcrop were inconsistent in their dynamism. It was noticed that vegetation land cover increased by $428.68 \mathrm{~km}^{2}$ between 1991 and 2002 but decreased by $60.93 \mathrm{~km}^{2}$ between 2002 and 2015. The observed irregular pattern in land use dynamism may partly be attributed to the

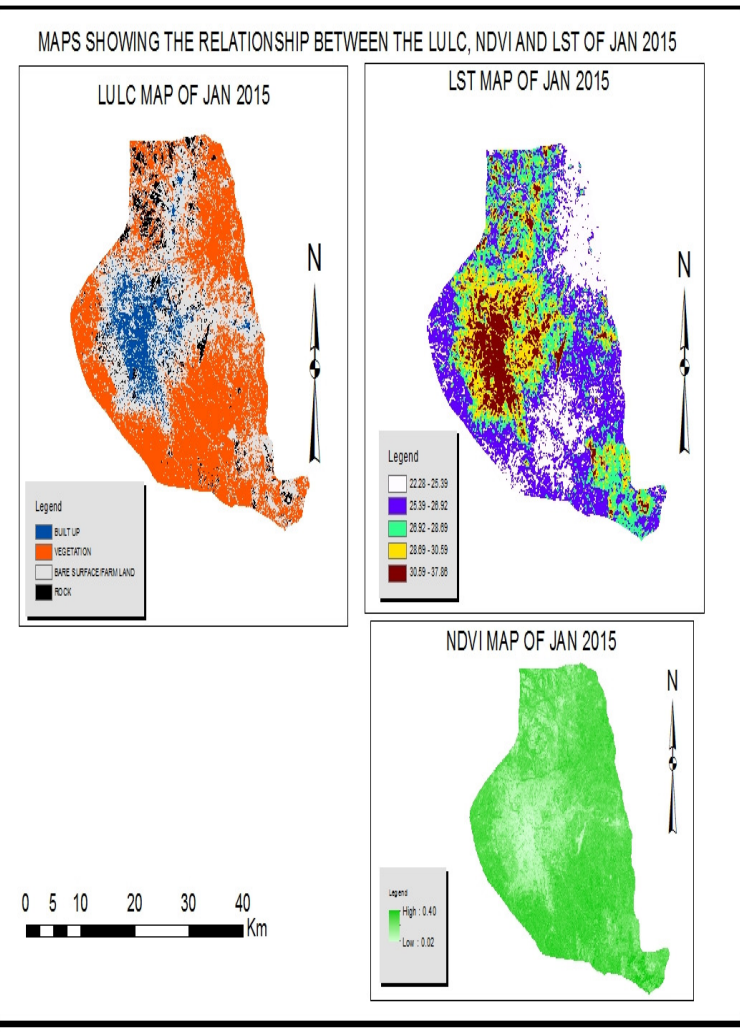

Figure 5 (c) showing the relationship between LULC, LST and NDVI of the study area in 2015

implementation of Government policies on agriculture and land developments in Nigeria then that were not favourable to farmers (Iwuchukwu and Igbokwe, 2012). Consequent upon this, farmlands were abandoned and overgrown by vegetation as reflected in the reduction observed in farmland in 2002.

The LSTs of all the identified land use types were shown in Table 4. The analysis indicated that built-up land use exhibited highest mean LST values in the 3 years $\left(29.3^{\circ} \mathrm{C}\right.$ in $1991,30.1^{\circ} \mathrm{C}$ in 2002 and $34.2^{\circ} \mathrm{C}$ in 2015), followed by rock outcrops $\left(26.1^{\circ} \mathrm{C}\right.$ in $1991,21.9^{\circ} \mathrm{C}$ in 2002 and $29.6^{\circ} \mathrm{C}$ in 2015), farmland $\left(24.7^{\circ} \mathrm{C}\right.$ in $1991,18.5^{\circ} \mathrm{C}$ in 2002 and 
$27.8^{\circ} \mathrm{C}$ in 2015$)$ and vegetation $\left(22.0^{\circ} \mathrm{C}\right.$ in $1991,16.3^{\circ} \mathrm{C}$ in 2002 and $23.8^{\circ} \mathrm{C}$ in 2015). As depicted from the LST maps (Figures $4 \mathrm{a}, \mathrm{b} \& \mathrm{c}$.), the highest surface temperature was recorded in built-up area of Akure metropolis, the administrative capital of Ondo State and also along Itaogbolu/Iju (headquarters of Akure North LGA) axis. This is because builtup areas are predominately composed of materials and structures which are mostly non-transpiring and non-evaporating. These materials tend to absorb more of the heat energy from the sun in their dense mass. When the heat is released mainly at night, it raises the air temperature as well as increases the consumption of energy in buildings. Urban areas are generally composed of surfaces which are rough and dry, as natural vegetated surfaces are replaced with impervious surfaces that hinder solar radiation from penetrating through them (Xian and Mike, 2004) and thus increasing heat energy by dissipating the radiation into the surroundings. Similar to built-up land use in terms of material and structures is the rock outcrop that recorded LST values higher than that of farmland and vegetation throughout the study period. However, the LST value of farmland is higher than that of vegetation as it is the most evaporative and transpirative surface for heat energy. In general, the changes in land surface temperatures of the various land uses between 1991 and 2015 shows that buildup has temperature increase by $4.9^{\circ} \mathrm{C}$ followed by rock outcrops $\left(3.5^{\circ} \mathrm{C}\right)$, farmland $\left(3.1^{\circ} \mathrm{C}\right)$ and vegetation $\left(1.9^{\circ} \mathrm{C}\right)$. It is therefore suffice to say that an increase of $68.15 \mathrm{~km}^{2}$ in the built up area generated a corresponding surface temperature increase of $4.9^{\circ} \mathrm{C}$ in the study period; a value which may likely be more in the central business district (CBD) as observed in Akure by Akinbode et al. (2008), Beijing, China, (Svensson and Tarvainen, 2004) .

The health implication of these values are that the urban dwellers may be subjected to some levels of weather related physiological disorder such as irritability, loss of concentration and ability to do mental tasks or engage in heavy work; as it has been confirmed that environmental temperature that rises above $30^{\circ} \mathrm{C}$ will interfere with the performance of mental tasks (Canadian Center for Occupational Health and Safety, 2016). The temperature observed in the study area further confirmed the observation of US EPA (2016) that 2001 to 2010 was the warmest decade ever recorded all over the world which is an indication of climatic change phenomenon.

\section{Conclusion}

The study has shown the versatility of remote sensing data and GIS approach in assessing LSTs of various land use types in rapidly developing Akure Region of Ondo State between 1991 and 2015. The study examined the spatial distribution of urban surface temperature according to land-cover types and NDVI with remotely sensed data from which urban development has a significant impact on radiant surface temperature. The study also confirmed that urban development had increased surface radiant temperature in the study area by $4.9^{\circ} \mathrm{C}$ within 24 years.

The study further attempted to provide solutions to one of the problems associated with the in situ data used for temperature as identified by Akinbode et 
al. (2008) that Nigeria lacks reasonable number of meteorological stations and frivolous data from such stations have hindered investigations into the urban climate change in Nigeria and in many developing countries of the world. Though, the LST value in the study area has not reached a critical stage, however, efforts should be geared towards ensuring proper land use management and encouraging practice of 'urban greeness', particularly in the urban centres to reduce the effects of increased LST on the urban dwellers.

\section{References}

Aderoju, O.M., Samakinwa, E.K. and Ibrahim, D. (2013). An Assessment of Urban Heat Island in Akure Using Geospatial Techniques. Journal of Environmental Science, Taxicology, 6(3): 24-34.

Akhoondzadeh, M. and Saradjian, M.R. (2008). Comparison of Land Surface Temperature mapping using MODIS and ASTER Images in Semi-Arid Area. The International Archives of the Photogrammetry, Remote Sensing and Spatial Information Sciences. Vol. XXXVII. Part B8. 873-876

Akinbode, O.M., Eludoyin, A.O. and Fashae, O.A. (2008). Temperature and relative humidity distributions in a medium-size administrative town in southwest Nigeria. Journal of Environmental Management, 87: 95-105.

Alavipanah1 S.K., Saradjian, M., Savaghebi, Gh.R., Komaki1, Ch. B., Moghimi, E. and Reyhan, M..K. (2007). Land Surface Temperature in the Yardang Region of Lut Desert (Iran) Based on Field
Measurements and Landsat Thermal Data. J. Agric. Sci. Technology, 9: 287-303.

Arnfield, A.J. (2003). Two decades of urban climate research: a review of turbulence, exchanges of energy and water, and the urban heat island. International Journal of Climatology, 23: 1- 26.

Ayeni, A.O. (2011). Malaria Morbidity in Akure, Southwest, Nigeria: A Temporal Observation in a Climate Change Scenario. Trends in Applied Sciences Research, 6: 488-494.

Barbour, K., J.S. Oguntoyinbo, J.O.C. Onyemelukwe and J.C. Nwafor, 1982. Nigeria in Maps. Nigerian Publishers, Ibadan.

Bindi, M., Brandani, G., Dessì A., Dibari, C., Ferrise, R., Moriondo, M. and Trombi, G. (2009). Impact of Climate Change on Agricultural and Natural Ecosystems, Am. J. Environ. Sci., 5(5): 633-638.

Canadian Center for Occupational Health and Safety (2016). Hot environmental-health effects and first aid. Canadian Government, Canada.

Cohen, J.E. (2004). How Many People Can the Earth Support? W.W. Norton \& Co.New York.

Effat, H.A. and Hassan, O.A.K. (2014). Change detection of urban heat islands and some related parameters using multi-temporal Landsat images; a case study of Cairo city, Egypt. Urban Climate, 10: 171-188

Federal Bureau of Statistic (2007). Federal Republic of Nigeria Official Gazette. Vol. 94, Federal Government Printer, Lagos, Nigeria. 
Spatio-Temporal Analysis of Land Surface Temperature Variations.................IBITOYE et al.

Feizizadeh, B and Blaschke, T. (2013). Examining Urban Heat Island Relations to Land Use and Air Pollution: Multiple Endmember Spectral Mixture Analysis for Thermal Remote Sensing. IEEE Journal Of Selected Topics in Applied Earth Observations and Remote Sensing, 6(3): 1749-1756.

Ifatimehin O.O., Musa S.D., Adeyemi J. O. (2011). Managing Land Use Transformation and Land Surface Temperature Change in Anyigba Town, Kogi State, Nigeria. Journal of Geography and Geology, 3(1): 77-85.

Iloeje, N.P. (1977). A New Geography of Nigeria. Longman Nigeria Ltd., Ibadan, pp: 260.

Iwuchukwu, J.C. and Igbokwe, E.M. (2012). Lessons from Agricultural Policies and Programmes in Nigeria Journal of Law, Policy and Globalization, 5: 11- 21.

Lo, C.P. and Quattrochi, D.A. (2003). Land-use and land-cover change, urban heat island phenomenon, and health implications: A remote sensing approach. Photogramm. Eng. Remote Sens., 69: 1053-1063.

Mather, P.M. (1999). Computer Processing of Remotely Sensed Imageries-An Introduction. John Wiley and Sons, Toronto

Musa, J., Bako, M. M., Yunusa, M. B., Kuta G. I., and Masa, A. (2012). An assessment of the impact of urban growth on land surface temperature in FCT Abuja using geospatial technique. Sokoto Journal of the Social Sciences, 2(2): 144-160.

Rajendran, S., Rajamanickan, M., Sivakumar, R. and Murali Mohan, K. R. (2009). Hyperspetral Remote
Sensing and its Applications in Rajendran, S., Rajamanickan, M., Sivakumar, R., and Murali Mohan, K. R(eds). Hyperspetral Remote Sensing and spectral signature Applications. New India Publication Agency, New Delhi pp 23-47

Rajeshwari, A. and Mani, N.D. (2014). Estimation of land surface temperature of Dindigul district using landsat 8 data. International Journal of Research in Engineering and Technology, 3(5): 122-126

Rosa, E.A., York, R. and Dietz, T. (2004). Tracking the Anthropogenic Drivers of Ecological Impacts. Ambio: A Journal of the Human Environment, 33(8): 509-512.

Sackey, A.N.A. (2008). Environmental Impacts of Rapid Urbanization of Ethiopia's Cities In M.P. Van Dijk and J. Fransen (eds) Managing Ethiopian Cities in an Era of Rapid Urbanization. Eburon Delft. Pp. 119-131

Samuels, R. (2004). Urban Heat Islands. Australian House of Representative Standing Committee on Environment and Heritage Sustainable Cities 2025 Enquiry.

Singh, R. B. Grover, A and Zhan, J. (2014). Inter-Seasonal Variations of Surface Temperature in the Urbanized Environment of Delhi Using Landsat Thermal Data. Energie, 7: 1811-1828

Svensson, D. and Tarvainen, L. (2004). The Past and Present Urban Heat Island of Beijing, B416 Projektarbete Goteborg, Earth Sciences. Goteborg University, Sweden. 
Uluocha, N.O. and Ekop, G. (2002). Nigeria: Geography. In: History and Cultures of Nigeria up to 2000, Osuntokun, A., D. Aworawo and F. Masajuwa (Eds.). Frankad Publishers, Lagos, Nigeria pp: 3-19.

US EPA (2016). A student's guide to global climatic change. Environmental Protection Agency Publications, US.

Valsson, S. and Bharat, A. (2009). Urban Heat Island: Cause for Microclimate Variations. Architecture-Time Space \& People, 21-25.

Voogt, J.A. and Oke, T.R. (2003). Thermal remote sensing of urban climates. Remote Sens. Environ., 86: 370-384.

Xian, G. and Mike, C. (2004). Evaluation of Urbanization Influences on Urban Climate with Remote Sensing and Climate Observations. SAIC/USGS National Center for Earth Resources Observation and Science, Sioux falls, SD 57198, 1-7.
Xu, H.O. and Chen, B.Q. (2004). Remote Sensing of the Urban Heat Island \& Its Changes in Xiamen City of SE China, Journal of Environmental Sciences 16(2): 276281.

Yue, W., Xu, J., Tan, W. and $\mathrm{Xu}, \mathrm{L}$. (2007). The relationship between land surface temperature and NDVI with remote sensing: Application to Shanghai Landsat 7 ETM+ data. Int. J. Remote Sens, 28: 3205-3226.

Zemba, A.A., Adebayo, A.A. and Musa, A.A. (2010). Evaluation of The Impact Of Urban Expansion On Surface Temperature Variations Using Remote Sensing-Gis Approach. Global Journal of Human Social Science, 10(2): 2029.

Zhang, J. and Wang, Y. (2008). Study of the Relationships between the spatial extent of surface urban heat islands and urban characteristic factors based on Landsat ETM+ Data. Sensors, 8: 7453-7468. 